\title{
Synthesis of Analcime Crystals and Simultaneous Potassium Extraction from Natrolite Syenite
}

\author{
Jian Chen, ${ }^{1,2,3}$ Hongwen Ma, ${ }^{1,2}$ Changjiang Liu,, ${ }^{1,2,3}$ and Jiangyan Yuan ${ }^{1,2,3}$ \\ ${ }^{1}$ School of Materials Science and Technology, China University of Geosciences, Beijing 100083, China \\ ${ }^{2}$ Beijing Key Laboratory of Materials Utilization of Nonmetallic Minerals and Solid Wastes, China University of Geosciences, \\ Beijing 100083, China \\ ${ }^{3}$ Blue Sky Technology Corporation, Beijing 100083, China
}

Correspondence should be addressed to Hongwen Ma; mahw@cugb.edu.cn

Received 23 January 2017; Accepted 23 February 2017; Published 9 March 2017

Academic Editor: Santiago Garcia-Granda

Copyright (C) 2017 Jian Chen et al. This is an open access article distributed under the Creative Commons Attribution License, which permits unrestricted use, distribution, and reproduction in any medium, provided the original work is properly cited.

Analcime single crystals were successfully synthesized from natrolite syenite powder $\left(\mathrm{K}_{2} \mathrm{O} 10.89 \%\right)$ and $92.6 \%$ of potassium was extracted simultaneously by means of soda roasting followed by alkali-hydrothermal method. Effects of $\mathrm{NaOH}$ concentration, reaction temperature, and holding period on the analcime formation and potassium extraction were investigated systemically. The results indicated that $\mathrm{NaOH}$ concentration plays an important role in determining the chemical composition of zeolites and size distribution; by turning the $\mathrm{NaOH}$ concentrations, three different pure zeolites (i.e., the phillipsite-Na, the analcime, and the sodalite) were prepared. Besides, a higher temperature could accelerate the dissolution of $\mathrm{K}^{+}$ions and enhance the crystallinity degree of zeolite. The reactions involved in the analcime synthesis can be summarized as follows: sodium aluminum silicate dissolution $\rightarrow$ precipitation and dissolution of metastable zeolite-P $\rightarrow$ analcime nucleation $\rightarrow$ analcime growth. The extraction ratio of $\mathrm{K}^{+}$is associated with the types of synthesized zeolites, among which analcime is the most effective to promote potassium leaching out from zeolite lattice position. The optimal condition for analcime crystallization and $\mathrm{K}^{+}$leaching is found to be as follows: $175^{\circ} \mathrm{C}$ for $4 \mathrm{~h}$ in $0.5 \mathrm{~mol} / \mathrm{L} \mathrm{NaOH}$ solution.

\section{Introduction}

Analcime $\left(\mathrm{NaAlSi}_{2} \mathrm{O}_{6} \cdot \mathrm{H}_{2} \mathrm{O}\right)$ is a hydrated aluminosilicate mineral, the complex framework of which builds by cornersharing $\left[\mathrm{SiO}_{4}\right]$ and $\left[\mathrm{AlO}_{4}\right]$ tetrahedron resulting irregular channels and some cavities occupied by the exchangeable $\mathrm{Na}-$ ions in the crystal lattice $[1,2]$. Such unit cell structure and chemical properties permit the analcime to have wide utilization in a number of fields, such as catalysts in petroleum industry [3, 4], fertilizers in agriculture [5], adsorbents in waste water treatment [6-9], and membranes in surfactants and gas separation [10].

Natural analcime can be found in cavities of altered mafic and some undersaturated volcanic rocks [11]; however, the commercial usage of natural analcime is quite limited due to the uneven distribution as well as the low purity [12]. Therefore, many efforts have been devoted to the synthesis of high purity analcime. Generally, analcime is prepared starting from pure chemical reagents using a hydrothermal crystallization method within the temperature range of 100$200^{\circ} \mathrm{C}$. For example, Yokomori and Idaka [13] took tetraethylorthosilicate and aluminum isopropoxide as silica and alumina source, respectively, with tetramethylammonium bromide as organic template for the synthesis of analcime. Liu et al. [14] used aluminum hydroxide, sodium hydroxide, and water glass as starting materials for synthesizing analcime. In addition to such an approach, there is also an emerging trend to use natural minerals, clays, rocks, industrial and agricultural wastes, such as perlite [6,7], kaolin [15], potassium-rich rocks [16, 17], coal fly ash [18], and rice husk ash [19], as raw materials for analcime synthesis, due to their advantages of wide distribution and lower cost. For example, Sandoval et al. [20] investigated the synthesis of analcime from natural clinker, and Atta et al. [15] obtained analcime after $72 \mathrm{~h}$ aging 
and $24 \mathrm{~h}$ reaction at $180^{\circ} \mathrm{C}$ by a hydrothermal reaction using rice husk ash and metakaolin as the sources of silica and alumina, respectively.

The two approaches have their advantages and disadvantages. The main disadvantages lie in the complex synthesis process (i.e., long aging and reaction time) and the use of expensive template which make it costly and difficult to industrialization; besides, those raw materials can solely provide the aluminum and/or silicon sources for zeolites. Therefore, finding alternative cheap raw material with all the necessary components for zeolite by a simple and economic method is of great significance.

Recently, Ma et al. [16] firstly proposed an idea to utilize quartz syenite (one kind of potassium-rich rocks) as raw material to synthesize analcime via an alkali-hydrothermal reaction (treated at $240^{\circ} \mathrm{C}$ for $4 \mathrm{~h}$ ). This approach takes full use of the aluminosilicate and alkali metal source for analcime preparation; at the same time, it can also extract potassium ions $\left(\mathrm{K}^{+}\right)$which can be used to prepare potassium fertilizer, the most rare fertilizers in China and India [21-24]. Lately, Yuan et al. [17] investigated the analcime synthesis as well as the simultaneous extraction of $\mathrm{K}^{+}$from $\mathrm{K}$-feldspar in $\mathrm{Na}_{2} \mathrm{SiO}_{3}$ solution, which could be realized by hydrothermal dissolution process at $250^{\circ} \mathrm{C}$ for $5 \mathrm{~h}$. These attempts not only explore the feasibility of preparing analcime zeolite from abundantly available resources, but also provide a new idea for $\mathrm{K}^{+}$extraction from insoluble potassium resources.

We notice that in the above mentioned reports the potassium extraction $(\sim 75 \%)$ is not ideally high and there exist impurities in analcime (microcline and biotite) caused by the incomplete decomposition of microcline and indissolubility of biotite in alkaline aqueous, which will hinder the practical industrial application. In this study, we report a simple and economic method (i.e., the soda roasting followed by alkalihydrothermal approach) to convert natrolite syenite (an important potassium-rich rock in China) into pure analcime and potassium salts. In this reaction, the effects of the $\mathrm{NaOH}$ concentration, crystallization temperature, and time on the formation of analcime zeolite and the extraction of $\mathrm{K}^{+}$ were studied in detail. The reaction mechanism of analcime synthesis and dissolution of $\mathrm{K}^{+}$ions was also discussed.

\section{Experimental}

2.1. Materials. The natrolite syenite sample was collected from Fengcheng City of Liaoning Province (China) and natrolite syenite powder (particle size $<74 \mu \mathrm{m}$ ) for this research was prepared by crushing and grinding. The main chemical composition of natrolite syenite powder is $\mathrm{SiO}_{2}$ $54.72 \mathrm{wt} \%, \mathrm{Al}_{2} \mathrm{O}_{3} 19.54 \mathrm{wt} \%, \mathrm{~K}_{2} \mathrm{O} 10.89 \mathrm{wt} \%$, and a small quantity of $\mathrm{Fe}_{2} \mathrm{O}_{3}, \mathrm{Na}_{2} \mathrm{O}, \mathrm{MgO}$, and $\mathrm{CaO}$ (Table 1). According to the results of $\mathrm{X}$-ray diffraction of the natrolite syenite powder (Figure 1(a)), the predominated mineral is microcline, natrolite, and biotite. Based on the principle of material balance [25], mineral composition of the powder is the following (wt $\%$ ): microcline 60.8 , natrolite 19.0 , biotite 6.4 , muscovite 6.4 , chlorite 4.1 , calcite 1.3 , sphene 1.6 , and apatite 0.4. Both soda and $\mathrm{NaOH}$ used were of analytical reagent

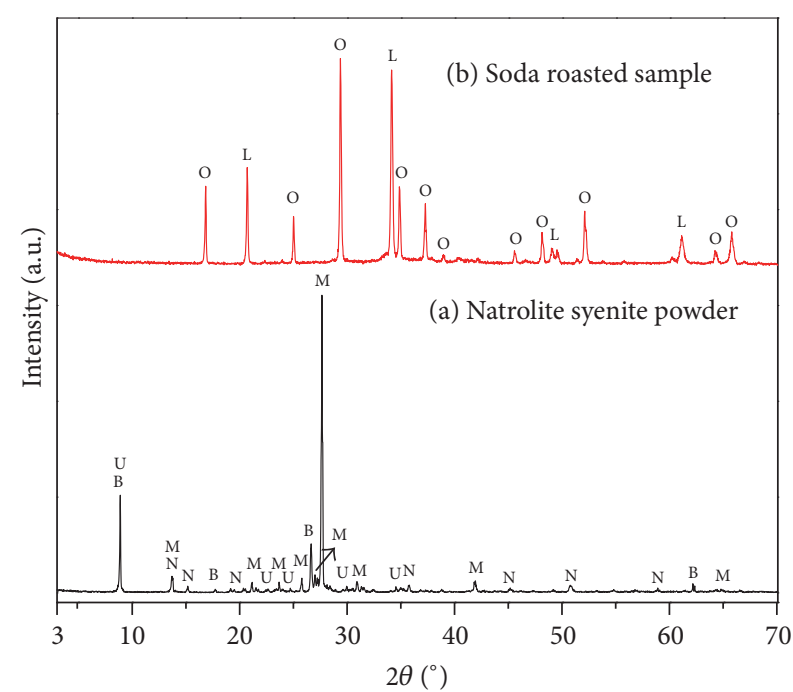

\footnotetext{
O: sodium silicate, $\mathrm{Na}_{2} \mathrm{SiO}_{3}$

$\mathrm{L}$ : sodium aluminum silicate, $(\mathrm{Na}, \mathrm{K}) \mathrm{AlSiO}_{4}$

$\mathrm{M}$ : microcline, $\mathrm{KAlSi}_{3} \mathrm{O}_{8}$

B: biotite, $\mathrm{K}(\mathrm{Mg}, \mathrm{Fe})_{3} \mathrm{AlSi}_{3} \mathrm{O}_{10}(\mathrm{OH})_{2}$

$\mathrm{N}$ : natrolite, $\mathrm{Na}_{2} \mathrm{Al}_{2} \mathrm{Si}_{3} \mathrm{O}_{10} \cdot 2 \mathrm{H}_{2} \mathrm{O}$

$\mathrm{U}$ : muscovite, $\mathrm{KAl}_{3} \mathrm{Si}_{3} \mathrm{O}_{10}(\mathrm{OH}, \mathrm{F})_{2}$
}

FIGURE 1: XRD patterns of natrolite syenite powder (a) and soda roasted sample (b).

grade (Beijing Chemical Reagent Ltd.) and all the solutions were diluted using deionized water.

2.2. Synthesis Experiments. In order to break the stable structure of microcline, natrolite, biotite, and muscovite for forming the active aluminosilicate to synthesize zeolite, and leaching out $\mathrm{K}^{+}$ions from hydrothermal product, the whole experiment was designed into two parts: soda roasting and hydrothermal crystallization. Firstly, roasting was conducted by placing the mixture of natrolite syenite powder and soda with $1: 1$ (mass ratio) in an electrically heated furnace at $830^{\circ} \mathrm{C}$ for $2 \mathrm{~h}$. XRD patterns of the natrolite syenite powder and soda roasted sample are shown in Figure 1, indicating that the main minerals in natrolite syenite were completely transformed into sodium silicate $\left(\mathrm{Na}_{2} \mathrm{SiO}_{3}\right)$ and sodium aluminum silicate $\left((\mathrm{Na}, \mathrm{K}) \mathrm{AlSiO}_{4}\right)$ after roasting with soda; the same results were obtained in our previous study by soda roasting with coal fly ash [26]. According to the principle of material balance, the chemical composition of roasted sample can be expressed as $0.8 \mathrm{~K}_{2} \mathrm{O} \cdot 6.2 \mathrm{Na}_{2} \mathrm{O} \cdot 1.3 \mathrm{Al}_{2} \mathrm{O}_{3} \cdot 6.0 \mathrm{SiO}_{2}$, the mole ratio of silica to alumina is about 2.4 within the range of synthesis of analcime, and no additional silicon and alumina sources are required. Secondly, hydrothermal reactions were performed in a stainless steel autoclave. $10 \mathrm{~g}$ of roasted sample was mixed with $100 \mathrm{~mL}$ of different concentration of $\mathrm{NaOH}$ solutions and then added into autoclave and heated at 125 $225^{\circ} \mathrm{C}$ for different times, respectively. After reaction, the solid products were filtered, washed with distilled water repeatedly, and dried at $105^{\circ} \mathrm{C}$ for $12 \mathrm{~h}$. The filtrates and washing solutions were collected and diluted to $500 \mathrm{~mL}$ to measure potassium content. The schematic diagram of 
TABLE 1: Chemical composition of natrolite syenite powder (wt\%).

\begin{tabular}{lcccccccccccc}
\hline Samples & $\mathrm{SiO}_{2}$ & $\mathrm{TiO}_{2}$ & $\mathrm{Al}_{2} \mathrm{O}_{3}$ & $\mathrm{Fe}_{2} \mathrm{O}_{3}$ & $\mathrm{MnO}$ & $\mathrm{MgO}$ & $\mathrm{CaO}$ & $\mathrm{Na}_{2} \mathrm{O}$ & $\mathrm{K}_{2} \mathrm{O}$ & $\mathrm{P}_{2} \mathrm{O}_{5}$ & Loss & Total \\
\hline NS-1 & 54.72 & 0.78 & 19.54 & 4.11 & 0.01 & 1.15 & 1.93 & 3.26 & 10.89 & 0.16 & 3.32 & 99.87 \\
\hline
\end{tabular}

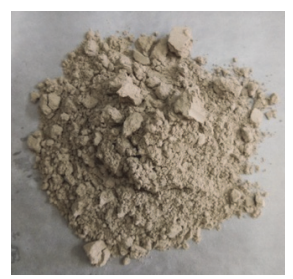

Nepheline syenite

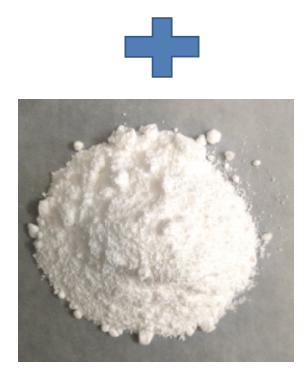

Soda powders

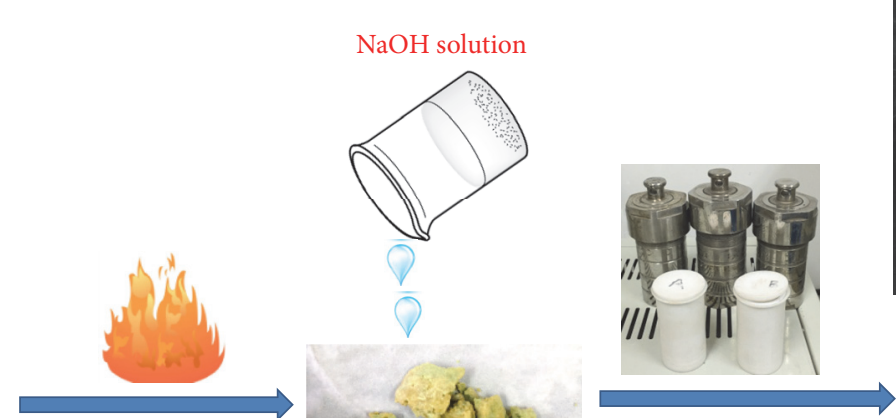

Roasting at $830^{\circ} \mathrm{C}$ for $2 \mathrm{~h}$

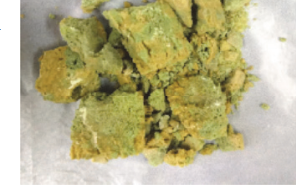

Roasted products

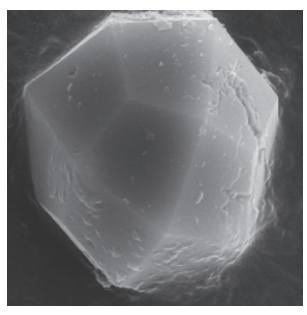

ANA zeolites

Hydrothermal reaction Filtration

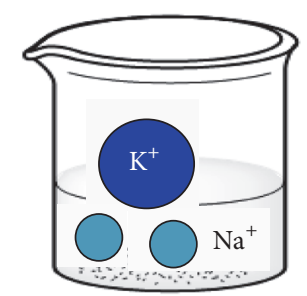

$(\mathrm{Na}, \mathrm{K})_{2} \mathrm{SiO}_{3}$

Solution

FIGURE 2: The schematic diagram of analcime synthesis with potassium extraction from natrolite syenite.

analcime synthesis with potassium extraction from natrolite syenite is shown in Figure 2.

2.3. Characterization. The chemical compositions of natrolite syenite powder were determined by wet chemical analysis. The contents of $\mathrm{SiO}_{2}$ and $\mathrm{Al}_{2} \mathrm{O}_{3}$ were determined by polyethylene oxide dehydration method and EDTA complexometric method, respectively. The X-ray diffraction (XRD) analysis was performed on a Rigaku D/Max 2500 X-ray diffractometer with $\mathrm{Cu} \mathrm{K} \alpha$ radiation. Data were collected over a $2 \theta$ range of $3-70^{\circ}$ with a step size of $0.02^{\circ}$ and scanning rate of $8^{\circ} \cdot \mathrm{min}^{-1}$. The microstructures of the solid samples were observed by field emission scanning electron microscopy with energy dispersive X-ray (SEM-EDX, Hitachi S-4800, Japan). FT-IR spectra of synthesized analcime were collected by Perkin Elmer 2000 FI-IR spectrometer in the $4000-400 \mathrm{~cm}^{-1}$ region using potassium bromide as the diluent and binder. The contents of potassium in the resulting filtrates were measured by flame photometric method and the extraction ratio of potassium $\left(\eta \mathrm{K}_{2} \mathrm{O} \%\right)$ was calculated by the following formula:

$$
\begin{aligned}
\eta \mathrm{K}_{2} \mathrm{O} & =\frac{C_{K} \times 0.5}{\left(\left(m_{1} \times \gamma \times 10.89 \%\right) / m_{2}\right) \times 10} \times 100 \% \\
& =\frac{0.459 \times C_{K} \times m_{2}}{m_{1} \times \gamma} \times 100 \% .
\end{aligned}
$$

$m_{1}$ denotes the weight of the mixture powder of natrolite syenite and soda before roasting $(\mathrm{g}), m_{2}$ represents the weight of the mixture powder after roasting $(\mathrm{g}), \gamma$ is the mass fraction of natrolite syenite in mixture powder before roasting, and $C_{K}$ is the contents of $\mathrm{K}_{2} \mathrm{O}$ in the diluted solution $(\mathrm{g} / \mathrm{L})$.

\section{Results and Discussion}

3.1. Effect of $\mathrm{NaOH}$ Concentration. Phase diagram in $\mathrm{Na}_{2} \mathrm{O}$ $\mathrm{Al}_{2} \mathrm{O}_{3}-\mathrm{SiO}_{2}-\mathrm{H}_{2} \mathrm{O}$ system is the basis used to synthesize zeolites [27]. Due to the presence of $\mathrm{K}_{2} \mathrm{O}$ in raw material, the hydrothermal crystallization of analcime zeolite in this research can be extended to the phase equilibrium of $\mathrm{K}_{2} \mathrm{O}$ $\mathrm{Na}_{2} \mathrm{O}-\mathrm{Al}_{2} \mathrm{O}_{3}-\mathrm{SiO}_{2}-\mathrm{H}_{2} \mathrm{O}$. To investigate the effect of $\mathrm{NaOH}$ concentration on the formation of analcime and the dissolution of $\mathrm{K}^{+}$ions, the hydrothermal experiment was performed in $0.0,0.5,1.0,1.5,2.0$, and $2.5 \mathrm{~mol} / \mathrm{L} \mathrm{NaOH}$ solutions at $175^{\circ} \mathrm{C}$ for $4 \mathrm{~h}$, respectively. The XRD patterns of the synthesized products are shown in Figure 3. It is apparent that three different zeolites, phillipsite- $\mathrm{Na}\left(\mathrm{Na}_{4} \mathrm{KAl}_{5} \mathrm{Si}_{11} \mathrm{O}_{32} \cdot 10 \mathrm{H}_{2} \mathrm{O}\right.$, ICDD 73-1419), analcime $\left(\mathrm{Na}_{6} \mathrm{Al}_{6} \mathrm{Si}_{12} \mathrm{O}_{36} \cdot 6 \mathrm{H}_{2} \mathrm{O}\right.$, ICDD 76-0906), and sodalite $\left(\mathrm{Na}_{8} \mathrm{Al}_{6} \mathrm{Si}_{6} \mathrm{O}_{24}(\mathrm{OH})_{2} \cdot 2 \mathrm{H}_{2} \mathrm{O}\right.$, ICDD 76-1639), can be obtained in the $\mathrm{K}_{2} \mathrm{O}-\mathrm{Na}_{2} \mathrm{O}-\mathrm{Al}_{2} \mathrm{O}_{3}-\mathrm{SiO}_{2}-\mathrm{H}_{2} \mathrm{O}$ system. The lower $\mathrm{NaOH}$ concentration $(0.0 \mathrm{~mol} / \mathrm{L})$ is in favor of phillipsite- $\mathrm{Na}$ formation, and higher concentration of $\mathrm{NaOH}$ (1.0-2.5 mol/L) accelerated the formation of sodalite. The results are in good agreement with the report of previous 
TABLE 2: The phase composition of as-prepared product and the extraction rates of potassium under different concentrations of $\mathrm{NaOH}$ solution.

\begin{tabular}{|c|c|c|c|c|c|c|c|}
\hline \multirow{4}{*}{$\begin{array}{l}\text { Samples } \\
\text { SM-0 }\end{array}$} & \multicolumn{3}{|c|}{ Experiment conditions } & \multicolumn{4}{|c|}{ Results } \\
\hline & $\begin{array}{l}\mathrm{C}_{\mathrm{NaOH}} \\
(\mathrm{mol} / \mathrm{L})\end{array}$ & $\begin{array}{c}T \\
\left({ }^{\circ} \mathrm{C}\right)\end{array}$ & $\begin{array}{c}t \\
(\mathrm{~h})\end{array}$ & \multicolumn{2}{|c|}{ Solid product phase composition } & $\begin{array}{l}\mathrm{Si} / \mathrm{Al} \\
\text { ratio }\end{array}$ & $\begin{array}{c}\eta \mathrm{K}_{2} \mathrm{O} \\
(\%)\end{array}$ \\
\hline & \multirow{2}{*}{\multicolumn{3}{|c|}{ Soda roasting at $830^{\circ} \mathrm{C}$ for $2 \mathrm{~h}$}} & Sodium silicate & $\mathrm{Na}_{2} \mathrm{SiO}_{3}$ & & \\
\hline & & & & \multicolumn{2}{|c|}{$\begin{array}{l}\text { Sodium alumina silicate } \\
\qquad(\mathrm{Na}, \mathrm{K})_{4} \mathrm{Al}_{2} \mathrm{Si}_{2} \mathrm{O}_{9}\end{array}$} & 2.4 & - \\
\hline SM-1 & 0.0 & 175 & 4 & Phillipsite-Na & $\mathrm{Na}_{4} \mathrm{KAl}_{5} \mathrm{Si}_{11} \mathrm{O}_{32} \cdot 10 \mathrm{H}_{2} \mathrm{O}$ & 2.1 & 54.6 \\
\hline SM-2 & 0.5 & 175 & 4 & Analcime & $\mathrm{NaAlSi}_{2} \mathrm{O}_{6} \cdot \mathrm{H}_{2} \mathrm{O}$ & 2.0 & 92.6 \\
\hline SM-3 & 1.0 & 175 & 4 & Sodalite & $\mathrm{Na}_{8} \mathrm{Al}_{6} \mathrm{Si}_{6} \mathrm{O}_{24}(\mathrm{OH})_{2} \cdot 2 \mathrm{H}_{2} \mathrm{O}$ & 1.0 & 86.5 \\
\hline SM-4 & 1.5 & 175 & 4 & Sodalite & $\mathrm{Na}_{8} \mathrm{Al}_{6} \mathrm{Si}_{6} \mathrm{O}_{24}(\mathrm{OH})_{2} \cdot 2 \mathrm{H}_{2} \mathrm{O}$ & 1.0 & 86.4 \\
\hline SM-5 & 2.0 & 175 & 4 & Sodalite & $\mathrm{Na}_{8} \mathrm{Al}_{6} \mathrm{Si}_{6} \mathrm{O}_{24}(\mathrm{OH})_{2} \cdot 2 \mathrm{H}_{2} \mathrm{O}$ & 1.0 & 86.0 \\
\hline SM-6 & 2.5 & 175 & 4 & Sodalite & $\mathrm{Na}_{8} \mathrm{Al}_{6} \mathrm{Si}_{6} \mathrm{O}_{24}(\mathrm{OH})_{2} \cdot 2 \mathrm{H}_{2} \mathrm{O}$ & 1.0 & 85.9 \\
\hline
\end{tabular}

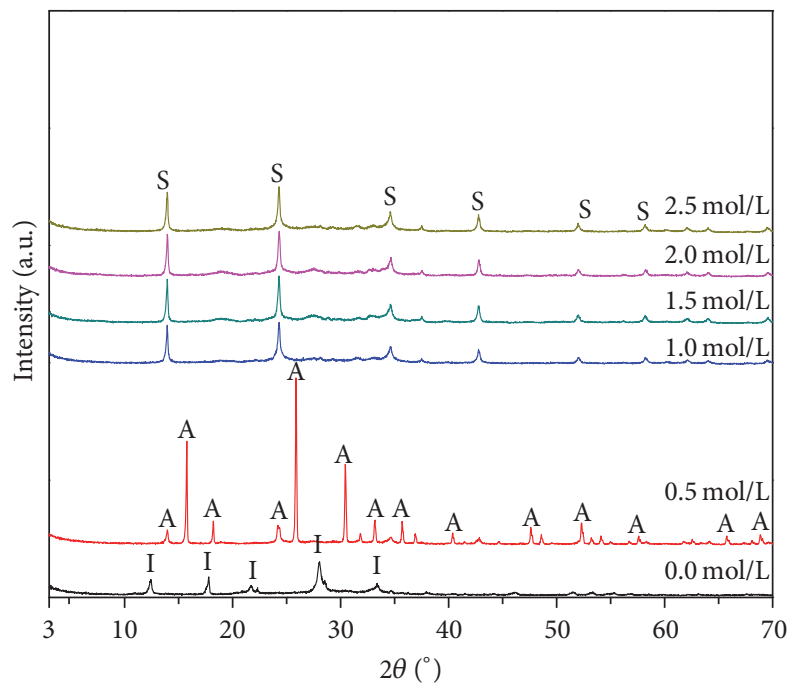

S: sodalite

A: analcime

I: phillipsite- $\mathrm{Na}$

FIGURE 3: XRD patterns of products prepared under different $\mathrm{NaOH}$ concentrations.

study $[28,29]$. It was also shown that pure analcime could only be synthesized at $0.5 \mathrm{~mol} / \mathrm{L} \mathrm{NaOH}$ solutions, and the diffraction peaks at $2 \theta=15.8^{\circ}, 25.9^{\circ}$, and $30.6^{\circ}$ are in accordance with the high crystallinity analcime crystals synthesized from chemical-grade reagents $[3,13,19]$. The results indicated that $\mathrm{NaOH}$ concentration plays an important role in determining the chemical composition of synthesized zeolite.

Figure 4 shows the SEM images of the samples prepared at different $\mathrm{NaOH}$ concentrations. The SEM results are in good consistence with XRD analysis. The phillipsite-Na zeolite with poor crystallinity and cotton-like morphology is shown in Figure 4(a). The icositetrahedra crystal with average size of $10 \mu \mathrm{m}$ was identified as analcime in Figure 4(b), which is similar to the morphology of analcime obtained by using clinker [20], rice husk ash [15], and quartz syenite [16] as raw materials. It was also shown that most of analcime crystals are clean facetted, and some fractures exhibited may be associated with the presence of metallic impurities of Fe and $\mathrm{Ti}$ in natrolite syenite. According to previous study [30, 31], the additions of $\mathrm{Fe}$ and/or $\mathrm{Ti}$ into a synthesis mixture in preparation of zeolite led to structural defects in the analcime produced. As the $\mathrm{NaOH}$ concentration was higher than $0.5 \mathrm{~mol} / \mathrm{L}$, the spherical sodalite with surface covered by short columnar crystals appeared (Figure 4(c) and Figure 4(d)). Analcime and sodalite crystals with uniform size distribution are shown in Figure 4, indicating that the presence of metallic impurities and the increase of $\mathrm{NaOH}$ concentration help to narrow the size distribution of particles. The results proved that, with hydrothermal crystallization treated at $0.5 \mathrm{~mol} / \mathrm{L}$ $\mathrm{NaOH}$ solution, the pure, single-phase analcime crystals with diameter of $10 \mu \mathrm{m}$ could be obtained.

Table 2 shows the phase composition of as-prepared product and extraction ratio of potassium under different concentrations of $\mathrm{NaOH}$ solution. It was found that the $\mathrm{Si} / \mathrm{Al}$ mole ratio of synthesized zeolites decreased from 2.1 to 2.0 and down to 1.0 finally with $\mathrm{NaOH}$ concentration increasing. This can be explained by the behavior of $\mathrm{Si}$ and $\mathrm{Al}$ in alkali aqueous, and higher alkalinity leads to higher solubility of the $\mathrm{Si}$ and Al sources, decreases the degree of silicate anion polymerization, and speeds up the polymerization of the polysilicate and aluminate anions [32, 33]. It was also observed that the extraction ratio of $\mathrm{K}^{+}$is associated with the types of synthetic zeolite. After phillipsite$\mathrm{Na}$ zeolite was synthesized in water, only $54.6 \%$ of $\mathrm{K}^{+}$ions were leaching, which may be caused by the remaining $\mathrm{K}^{+}$ ions required to balance the resulting net negative charge of the aluminosilicate framework structure in zeolite. However, synthesis of sodalite is corresponding to about $86.0 \%$ of $\mathrm{K}^{+}$extracted, and $92.6 \%$ of $\mathrm{K}^{+}$was recovered from the solution after analcime synthesis. The results reveal that analcime and sodalite formation would promote the $\mathrm{K}^{+}$ions leaching from zeolite lattice position, which could mainly be attributed to the limited ions exchange capacity with $\mathrm{K}^{+}$in both zeolites. According to the report by Barrer and Hinds $[34,35]$, analcime $\left(\mathrm{NaAlSi}_{2} \mathrm{O}_{6}\right)$ shows limited solid solubility of leucite $\left(\mathrm{KAlSi}_{2} \mathrm{O}_{6}\right)$ at both higher temperatures 


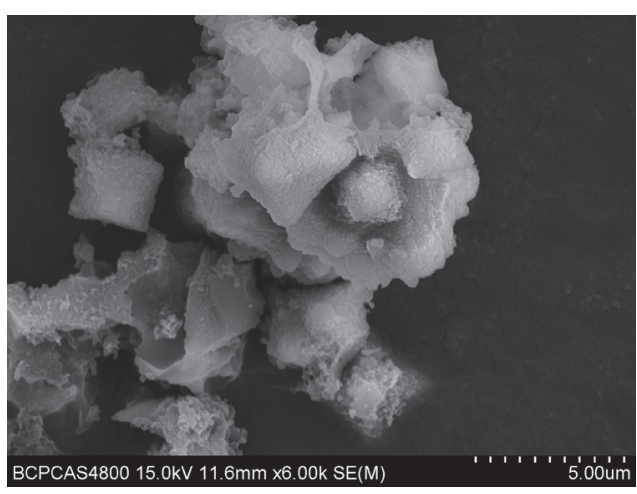

(a)

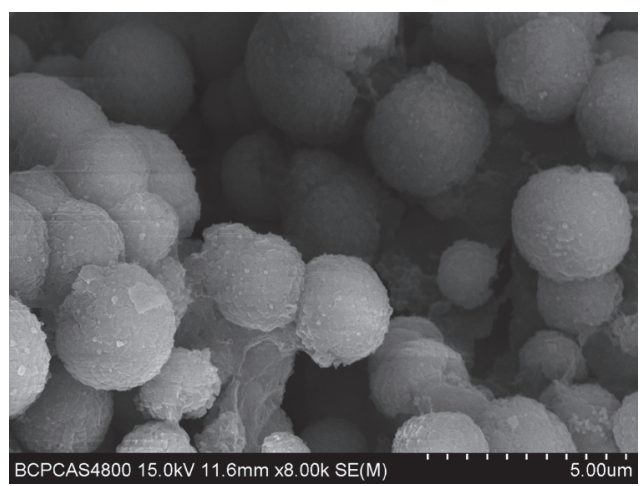

(c)

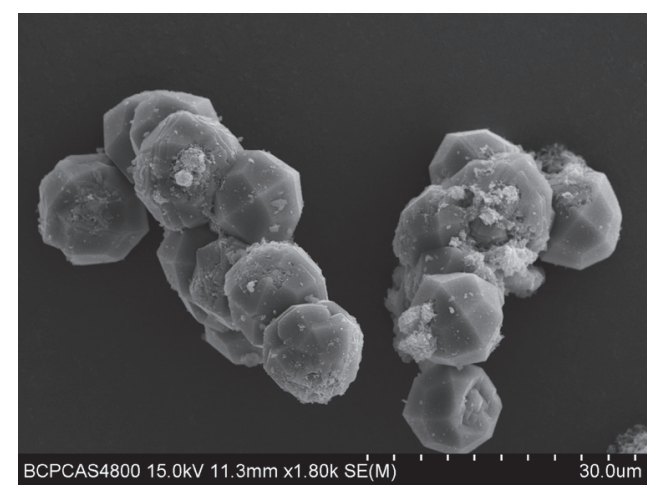

(b)

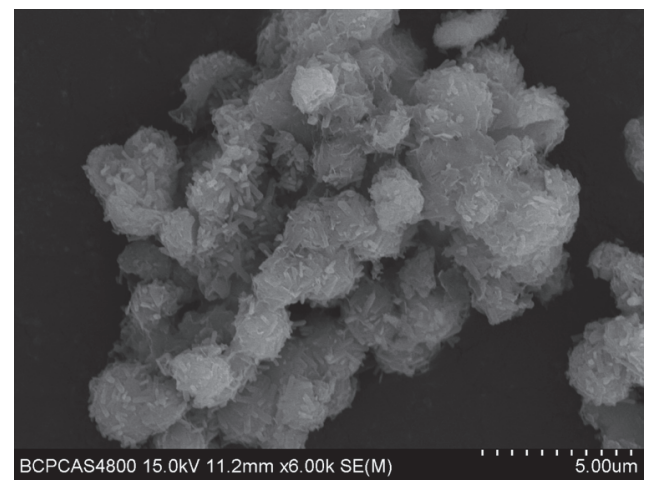

(d)

FIGURE 4: SEM images of samples prepared at different $\mathrm{NaOH}$ concentrations: (a) $0.0 \mathrm{~mol} / \mathrm{L}$, (b) $0.5 \mathrm{~mol} / \mathrm{L}$, (c) $1.0 \mathrm{~mol} / \mathrm{L}$, and (d) $1.5 \mathrm{~mol} / \mathrm{L}$.

and very low temperatures under hydrothermal conditions. Similarity results were obtained by Balgord and Roy [36]; in the case of $\mathrm{K}^{+}$exchange, no more than $10 \%$ of $\mathrm{K}^{+}$is tolerated in the analcime crystalline at equilibrium. The content of potassium component substituting in sodalite is in the ranges of $0.1 \%-5.3 \%$ according to the report by Taylor [37]. Thus, the optimal $\mathrm{NaOH}$ concentration for analcime preparation and $\mathrm{K}^{+}$leaching should be chosen as $0.5 \mathrm{~mol} / \mathrm{L}$.

3.2. Effect of Temperature. The effects of crystallization temperature on synthesis of analcime and leaching of $\mathrm{K}^{+}$were investigated under $0.5 \mathrm{~mol} / \mathrm{L}$ of $\mathrm{NaOH}$ solution at $125^{\circ} \mathrm{C} \sim$ $225^{\circ} \mathrm{C}$ for $4 \mathrm{~h}$. The XRD patterns of the solid samples and the results of potassium extraction ratio at different temperatures are shown in Figure 5. It can be seen that pure phase of zeolite$\mathrm{P}$ obtained in solid products is corresponding to $63.7 \%$ of $\mathrm{K}^{+}$ dissolved into mother liquor at $125^{\circ} \mathrm{C}$. When the temperature increased to $150^{\circ} \mathrm{C}$, the diffraction peaks corresponding to zeolite- $\mathrm{P}$ were enhanced and potassium extraction efficiency was also increased, indicating that a higher temperature could enhance the degree of crystallinity of zeolite [38] and accelerate the dissolution of $\mathrm{K}^{+}$. By increasing temperature from $150^{\circ} \mathrm{C}$ up to $175^{\circ} \mathrm{C}$, the zeolite-P disappeared completely and the pure analcime zeolite phase formed with the maximum of potassium extraction efficiency (92.6\%). However, when the temperature was above $175^{\circ} \mathrm{C}$, the phase of sodalite appeared in solid products, and the dissolution ratio of $\mathrm{K}^{+}$was reduced with the increase of temperature. These results indicated that both zeolite-P and analcime are metastable zeolites and have a tendency to convert into a more thermodynamically stable zeolite-sodalite with the temperature increasing [39-41]. On the other hand, it seems that analcime synthesized is more advantageous than sodalite to $\mathrm{K}^{+}$dissolution. In a word, a suitable temperature of $175^{\circ} \mathrm{C}$ is the most beneficial to the maximization of $\mathrm{K}^{+}$dissolution, which can reach $92.6 \%$.

FT-IR spectrum of analcime synthesized at $175^{\circ} \mathrm{C}$ is illustrated in Figure 6. The obtained peaks are similar to those of analcime single crystals reported in a previous study $[42,43]$. The peaks at $1003 \mathrm{~cm}^{-1}, 690 \mathrm{~cm}^{-1}$, and $576 \mathrm{~cm}^{-1}$ were assigned to $\mathrm{T}-\mathrm{O}(\mathrm{T}=\mathrm{Si}, \mathrm{Al})$ asymmetric stretch vibration, $\mathrm{T}$ $\mathrm{O}$ symmetric stretch vibration, and $\mathrm{T}-\mathrm{O}-\mathrm{T}$ bending vibration, respectively. The broad bands at $3420 \mathrm{~cm}^{-1}$ and $1654 \mathrm{~cm}^{-1}$ are attributed to zeolite water, and the bands at about $470 \mathrm{~cm}^{-1}$ are due to vibrations related to internal of the TO4. The lattice parameters of analcime zeolite synthesized at $175^{\circ} \mathrm{C}$ are shown in Table 3 , and the results are in good agreement with that of cubic analcime (ICDD 76-0976). The results indicated that the analcime with pure, single-phase, and high crystallinity was successfully synthesized at the crystallization temperature of $175^{\circ} \mathrm{C}$.

3.3. Effect of Crystallization Time. In order to explore the effects of crystallization time on the as-prepared products, the hydrothermal process was conducted at $175^{\circ} \mathrm{C}$ for different 

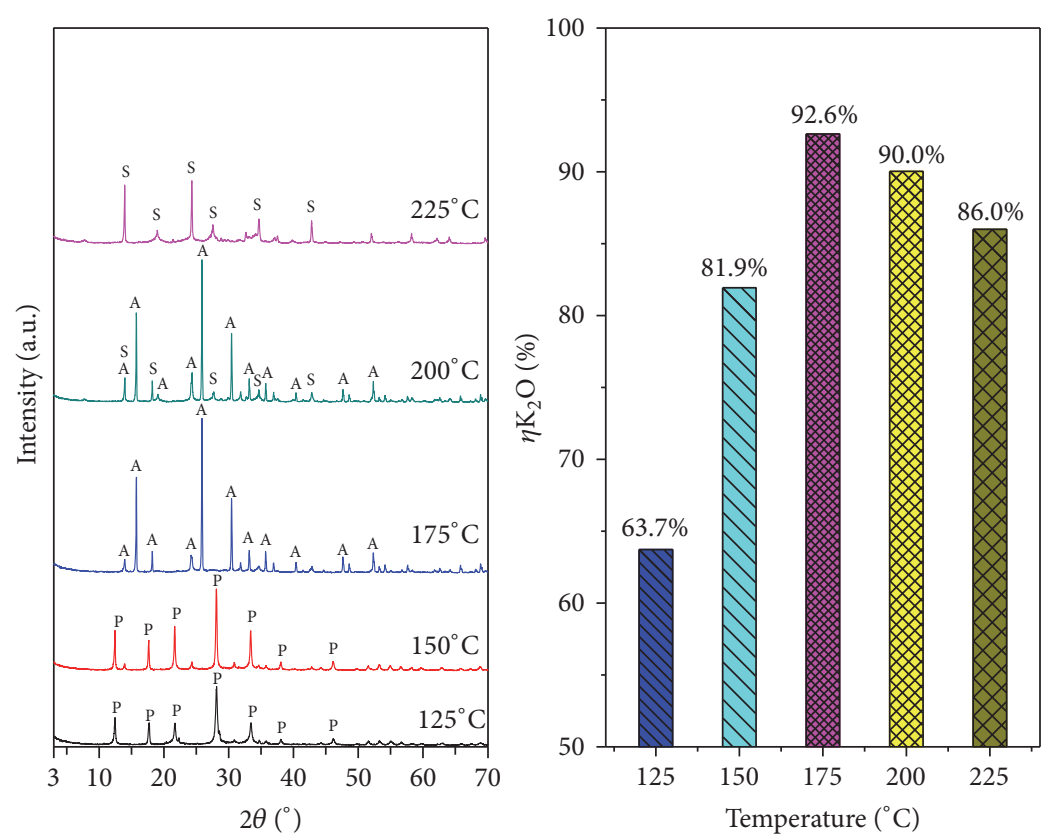

S: sodalite

A: analcime

P: zeolite P1

FIGURE 5: XRD patterns of the solid samples and the results of potassium extraction ratio at different temperatures.

TABLE 3: The calculated lattice parameters of prepared analcime obtained at optimal conditions.

\begin{tabular}{lcccccccc}
\hline Sample & $a(\AA)$ & $b(\AA)$ & $c(\AA)$ & $\alpha\left(^{\circ}\right)$ & $\beta\left(^{\circ}\right)$ & $\gamma\left(^{\circ}\right)$ & Cell volume $(\AA){\text { Cell density }\left(\mathrm{g} \cdot \mathrm{cm}^{-3}\right)}^{-}$ \\
\hline Analcime & 13.7568 & 13.7568 & 13.7597 & 90 & 90 & 90 & 2604.04 & 2.2462 \\
ICDD 76-0907 & 13.7210 & 13.7210 & 13.7350 & 90 & 90 & 90 & 2585.83 & 2.2620 \\
\hline
\end{tabular}

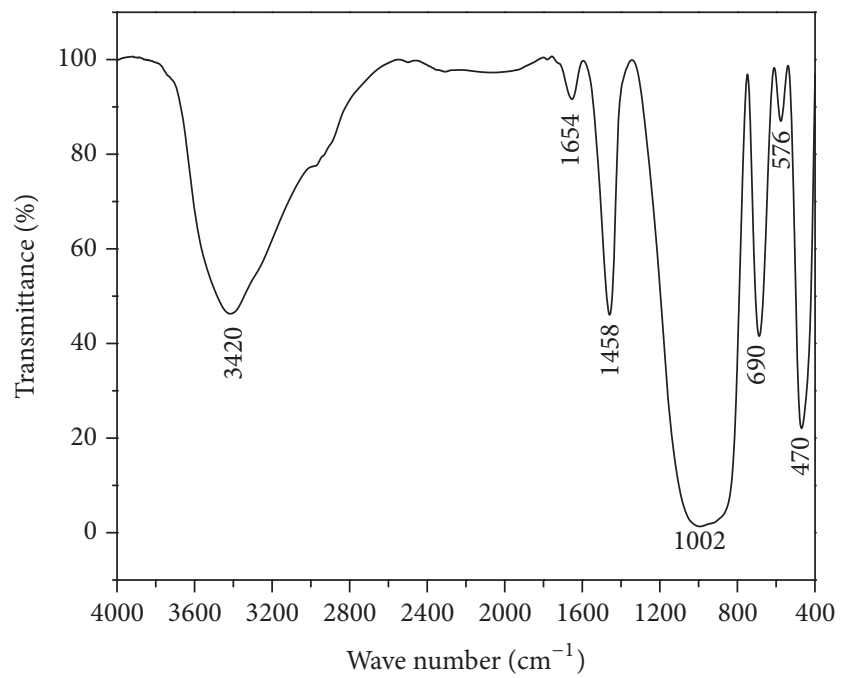

FIGURE 6: FT-IR spectrum of ANA zeolite synthesized in $0.5 \mathrm{~mol} / \mathrm{L}$ $\mathrm{NaOH}$ solutions at the crystallization temperature of $175^{\circ} \mathrm{C}$ for $4 \mathrm{~h}$.

crystallization times ( $1 \mathrm{~h}$ to $5 \mathrm{~h}$ ) in $0.5 \mathrm{~mol} / \mathrm{L} \mathrm{NaOH}$ solution. The XRD patterns of the products obtained at different crystallization time are presented in Figure 7. It is shown that the diffraction peaks of sodium aluminum silicate phase still existed after reaction for $1 \mathrm{~h}$, indicating that the dissolution rate of the precursor materials in the $\mathrm{NaOH}$ solution is slower than those using pure chemical agents as raw material. Therefore, it is clear that there is enough time to generate zeolite$\mathrm{P}$ nucleations in a supersaturated solution [44]. After twohour treatment, the zeolite-P product was detected. With the prolongation of the hydrothermal crystallization time to $3 \mathrm{~h}$, the metastable zeolite-P dissolved gradually and transformed into analcime zeolite. There is no crystalline phase of zeolite-P that appeared after $4 \mathrm{~h}$ treatment, and the products were pure analcime crystals; the analcime crystals were still stabilized after reaction for $5 \mathrm{~h}$. The results indicated that zeolite-P appears to be a metastable intermediate phase in the formation of analcime, and analcime zeolites could be obtained as the ultimate equilibrium phase in the initial batch of composition $8.0 \mathrm{~K}_{2} \mathrm{O} \cdot 115.9 \mathrm{Na}_{2} \mathrm{O} \cdot 13.3 \mathrm{Al}_{2} \mathrm{O}_{3} \cdot 63.3 \mathrm{SiO}_{2} \cdot 5550.0 \mathrm{H}_{2} \mathrm{O}$ at least for $4 \mathrm{~h}$.

The results of potassium extraction ratio at different crystallization time are shown in Figure 8, indicating that a significant increase in potassium extraction ratio was obtained by extending reaction time from $1 \mathrm{~h}$ to $4 \mathrm{~h}$. The $\mathrm{K}^{+}$ion dissolution reached equilibrium after hydrothermal treatment 


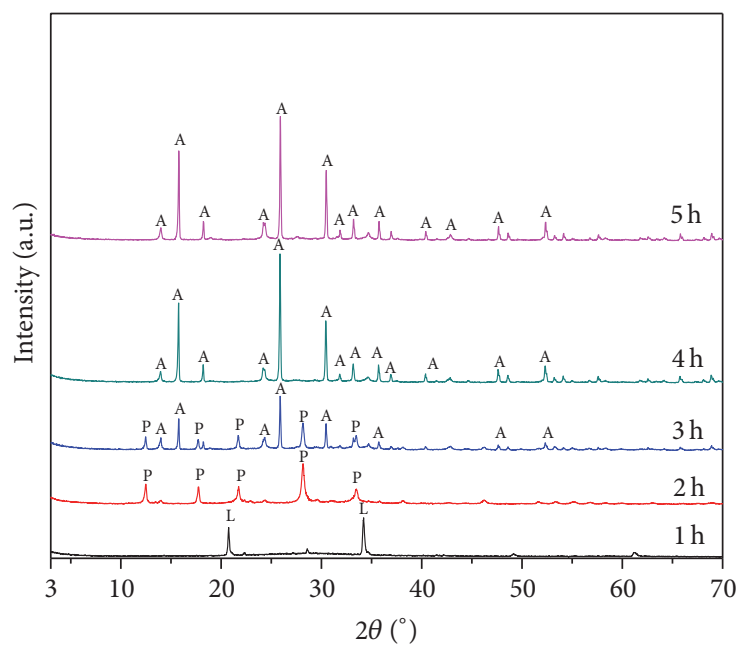

A: analcime
P: zeolite-P
L: sodium aluminum silicate

FIGURE 7: XRD patterns of the products obtained at different crystallization time.

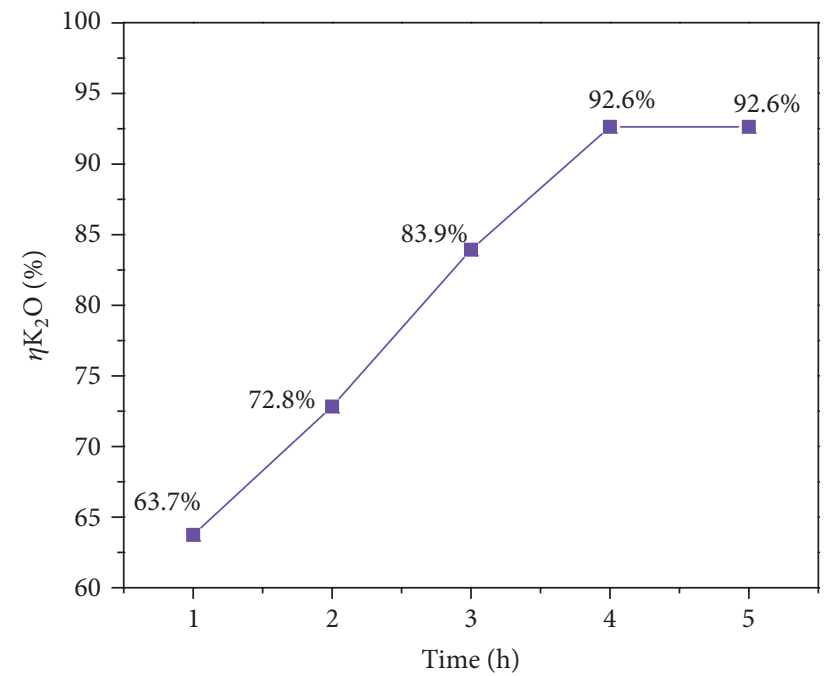

FIGURE 8: The results of potassium extraction rates at $175^{\circ} \mathrm{C}$ for different crystallization times ( $1 \mathrm{~h}$ to $5 \mathrm{~h}$ ) in $0.5 \mathrm{~mol} / \mathrm{L} \mathrm{NaOH}$ solution.

was prolonged to $4 \mathrm{~h}$, and the maximum of potassium extraction ratio reached was $92.6 \%$. Thus, the crystallization time for $4 \mathrm{~h}$ is appropriate for potassium extraction.

SEM images of the samples collected at different crystallization time are presented in Figure 9. The half-moonshaped particle with the size of about $4-6 \mu \mathrm{m}$ and smooth surface was identified as sodium aluminum silicate precursor (Figure 9(a)). The irregular octahedrons with surface accumulated by plate-like crystals were identified as zeolite$\mathrm{P}$ (Figure 9(b)), consistent with the previously reported in the literature [45]. With the reaction time extended, the irregular hollow octahedron structure of zeolite-P cracked (Figure 9(c)) and the icositetrahedra analcime crystals started crystallizing (Figure 9(d)). After 4 h crystallizing, the perfect icositetrahedra analcime single crystals with the uniform size of $10 \mu \mathrm{m}$ were obtained (Figures 9(e) and 9(f)). We can see that some small crystals emerged on the surface of intergrowths analcime crystals. According to the report by Ge et al. [46], when two particles with different sizes attach to each other, energetic factors drive the larger particle to grow, drawing from the smaller particle, which shrinks. In addition, the coincident results illustrated by SEM and XRD revealed that the reaction mechanism of the analcime synthesis could be summarized as follows: sodium aluminum silicate dissolution $\rightarrow$ precipitation and dissolution of metastable zeolite-P $\rightarrow$ analcime crystal nucleation $\rightarrow$ analcime crystal growth.

\section{Conclusions}

In this work, we successfully converted natrolite syenite into pure, single-phase, and high crystalline analcime zeolites with the average particle size of about $10 \mu \mathrm{m}$ via the soda roasting followed by alkali-hydrothermal method. In the process of hydrothermal crystallization, $92.6 \%$ of $\mathrm{K}^{+}$ions could simultaneously be dissolved. The optimal condition for analcime crystallization and $\mathrm{K}^{+}$leaching is found to be as follows: $175^{\circ} \mathrm{C}$ for $4 \mathrm{~h}$ in $0.5 \mathrm{~mol} / \mathrm{L} \mathrm{NaOH}$ solution. It was also concluded that (1) the $\mathrm{NaOH}$ concentration plays an important role in determining the chemical composition of zeolites and size distribution, (2) higher temperature could enhance the degree of crystallinity of zeolite and accelerate the dissolution of $\mathrm{K}^{+}$, (3) the mechanism of the analcime synthesis was summarized as sodium aluminum silicate dissolution $\rightarrow$ precipitation and dissolution of metastable zeolite- $\mathrm{P} \rightarrow$ analcime nucleation $\rightarrow$ analcime growth, and (4) the extraction ratio of $\mathrm{K}^{+}$is associated with the types of synthesized zeolites, among which analcime is the most 


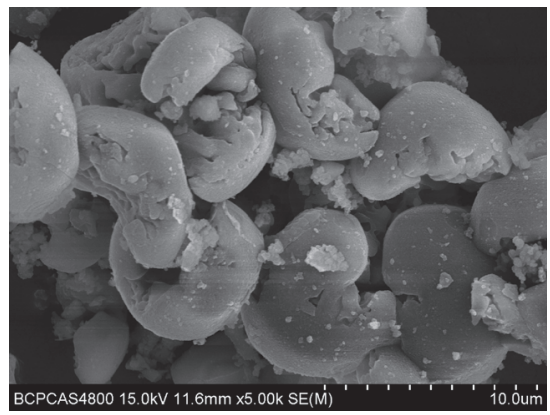

(a)

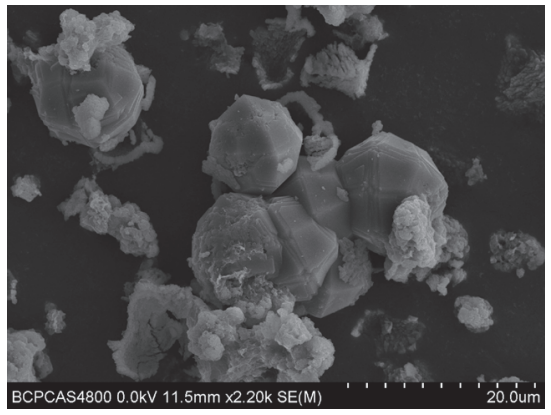

(d)

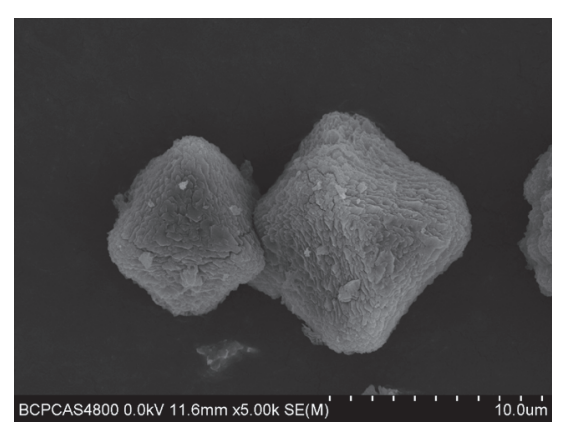

(b)

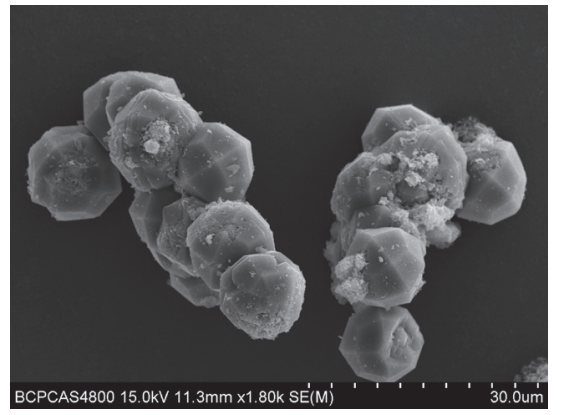

(e)

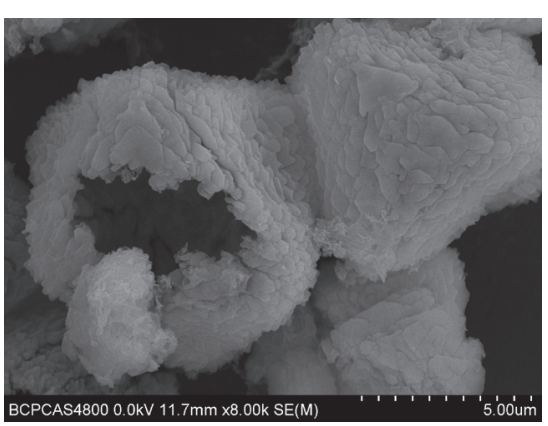

(c)

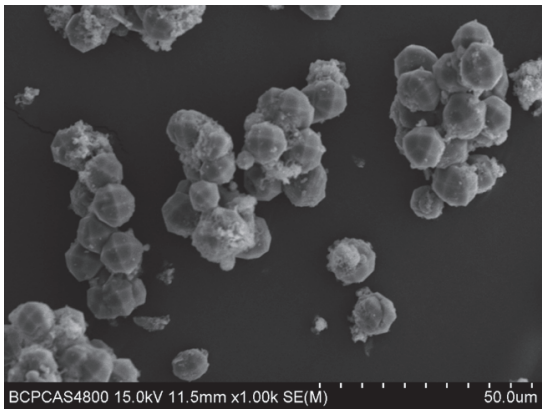

(f)

FIGURE 9: SEM images of samples collected at different crystallization time: (a) $1 \mathrm{~h}$, (b) $2 \mathrm{~h}$, (c) $3 \mathrm{~h}$, (d) $3 \mathrm{~h}$, (e) $4 \mathrm{~h}$, and (f) $5 \mathrm{~h}$.

effective to promote potassium leaching out from zeolite lattice position. As a result, this work successfully proved that the soda roasting and subsequent alkali-hydrothermal method were an economically available technique for the extraction of potassium and the synthesis of analcime from natrolite syenite, due to the comprehensive utilization of silicon, alumina, and potassium resources without additional expensive reagents needed.

\section{Conflicts of Interest}

The authors declare that they have no conflicts of interest.

\section{Acknowledgments}

This work was financially supported by Fundamental Research Funds for the Universities (Grant no. 2652015365) and the China Geological Survey Project (Grant no. 12120113087700).

\section{References}

[1] W. H. Taylor, "The structure of analcime $\left(\mathrm{NaAlSi}_{2} \mathrm{O}_{6} \cdot \mathrm{H}_{2} \mathrm{O}\right)$," Zeitschrift für Kristallographie, vol. 74, pp. 1-19, 1930.

[2] C. Baerlocher, L. B. McCusker, and D. H. Olson, Atlas of Zeolite Framework Types, Elsevier, Amsterdam, The Netherlands, 2001.

[3] S. N. Azizi and S. Ehsani Tilami, "Cu-modified analcime as a catalyst for oxidation of benzyl alcohol: experimental and theoretical," Microporous and Mesoporous Materials, vol. 167, pp. 89-93, 2013.
[4] A. Bejar, S. Ben Chaabene, M. Jaber, J.-F. Lambert, and L. Bergaoui, "Mn-analcime: synthesis, characterization and application to cyclohexene oxidation," Microporous and Mesoporous Materials, vol. 196, pp. 158-164, 2014.

[5] J. Yuan, J. Yang, H. Ma, and C. Liu, "Crystal structural transformation and kinetics of $\mathrm{NH}^{4+} / \mathrm{Na}^{+}$ion-exchange in analcime," Microporous and Mesoporous Materials, vol. 222, pp. 202-208, 2016.

[6] A. Dyer, S. Tangkawanit, and K. Rangsriwatananon, "Exchange diffusion of $\mathrm{Cu}^{2+}, \mathrm{Ni}^{2+}, \mathrm{Pb}^{2+}$ and $\mathrm{Zn}^{2+}$ into analcime synthesized from perlite," Microporous and Mesoporous Materials, vol. 75, no. 3, pp. 273-279, 2004.

[7] S. Tangkawanit, K. Rangsriwatananon, and A. Dyer, "Ion exchange of $\mathrm{Cu}^{2+}, \mathrm{Ni}^{2+}, \mathrm{Pb}^{2+}$ and $\mathrm{Zn}^{2+}$ in analcime (ANA) synthesized from Thai perlite," Microporous and Mesoporous Materials, vol. 79, no. 1-3, pp. 171-175, 2005.

[8] M. H. Mallah, H. Soorchi, and T. F. Jooybari, "Development of empirical equation for analcime in the treatment of nuclear waste," Annals of Nuclear Energy, vol. 47, pp. 140-145, 2012.

[9] Y. Zhang, Z. Jing, T. Kameda, and T. Yoshioka, "Hydrothermal synthesis of hardened diatomite-based adsorbents with analcime formation for methylene blue adsorption," RSC Advances, vol. 6, no. 32, pp. 26765-26774, 2016.

[10] A. Potdar, A. Shukla, and A. Kumar, "Effect of gas phase modification of analcime zeolite composite membrane on separation of surfactant by ultrafiltration," Journal of Membrane Science, vol. 210, no. 2, pp. 209-225, 2002.

[11] H. W. Ma, Industrial Minerals and Rocks, Chemical Industry, Beijing, China, 3rd edition, 2011.

[12] A. Balandis and A. Traidaraite, "The influence of Al containing component on synthesis of analcime of various crystallographic systems," Materials Science-Poland, vol. 25, no. 3, pp. 637-647, 2007. 
[13] Y. Yokomori and S. Idaka, "The crystal structure of analcime," Microporous and Mesoporous Materials, vol. 21, no. 4-6, pp. 365370, 1998.

[14] B. S. Liu, D. C. Tang, and C. T. Au, "Fabrication of analcime zeolite fibers by hydrothermal synthesis," Microporous and Mesoporous Materials, vol. 86, no. 1-3, pp. 106-111, 2005.

[15] A. Y. Atta, B. Y. Jibril, B. O. Aderemi, and S. S. Adefila, "Preparation of analcime from local kaolin and rice husk ash," Applied Clay Science, vol. 61, pp. 8-13, 2012.

[16] X. Ma, J. Yang, H. Ma, C. Liu, and P. Zhang, "Synthesis and characterization of analcime using quartz syenite powder by alkali-hydrothermal treatment," Microporous and Mesoporous Materials, vol. 201, pp. 134-140, 2015.

[17] J. Yuan, J. Yang, H. Ma, C. Liu, and C. Zhao, "Hydrothermal synthesis of analcime and hydroxycancrinite from K-feldspar in $\mathrm{Na}_{2} \mathrm{SiO}_{3}$ solution: characterization and reaction mechanism," RSC Advances, vol. 6, no. 59, pp. 54503-54509, 2016.

[18] X. Querol, N. Moreno, J. C. Umaña et al., "Synthesis of zeolites from coal fly ash: an overview," International Journal of Coal Geology, vol. 50, no. 1-4, pp. 413-423, 2002.

[19] S. N. Azizi and M. Yousefpour, "Synthesis of zeolites NaA and analcime using rice husk ash as silica source without using organic template," Journal of Materials Science, vol. 45, no. 20, pp. 5692-5697, 2010.

[20] M. V. Sandoval, J. A. Henao, C. A. Ríos, C. D. Williams, and D. C. Apperley, "Synthesis and characterization of zeotype ANA framework by hydrothermal reaction of natural clinker," Fuel, vol. 88, no. 2, pp. 272-281, 2009.

[21] H. W. Ma, J. Yang, S. Q. Su et al., "20 Years advances in preparation of potassium salts from potassic rocks: a review," Acta Geologica Sinica, vol. 89, pp. 1801-1840, 2014.

[22] D. Ciceri, D. A. C. Manning, and A. Allanore, "Historical and technical developments of potassium resources," Science of the Total Environment, vol. 502, pp. 590-601, 2015.

[23] T. Skorina and A. Allanore, "Aqueous alteration of potassiumbearing aluminosilicate minerals: from mechanism to processing," Green Chemistry, vol. 17, no. 4, pp. 2123-2136, 2015.

[24] U.S. Department of the Interior, U.S. Geological Survey. Mineral Commodity Summaries 2015, Potash, 2015.

[25] H. W. Ma, J. Yang, H. Liu, H. X. Li, Z. M. Bai, and Q. H. Wang, "Chemical equilibrium in silicate system part I, mass balance principle," Geoscience, vol. 20, pp. 329-339, 2006.

[26] Z. Q. Jiang, J. Yang, H. W. Ma, X. Ma, and J. Y. Yuan, "Synthesis of pure NaA zeolites from coal fly ashes for ammonium removal from aqueous solutions," Clean Technologies and Environmental Policy, vol. 18, no. 3, pp. 629-637, 2016.

[27] E. B. G. Johnson and S. E. Arshad, "Hydrothermally synthesized zeolites based on kaolinite: a review," Applied Clay Science, vol. 97-98, pp. 215-221, 2014.

[28] A. Rujiwatra, "A selective preparation of phillipsite and sodalite from perlite," Materials Letters, vol. 58, no. 14, pp. 2012-2015, 2004.

[29] M. Kohoutková, A. Kloužková, J. Maixner, and M. Mrázová, "Preparation and characterization of analcime by X-ray and SEM analyses," Ceramics-Silikáty, vol. 51, pp. 9-14, 2007.

[30] E. Z. Hegazy, I. H. A. El Maksod, and R. M. M. A. El Enin, "Preparation and characterization of Ti and V modified analcime from local kaolin," Applied Clay Science, vol. 49, no. 3, pp. 149-155, 2010.

[31] K. Katsuki, H. Suzuki, M. Hasegawa et al., "Effect of reaction temperature on $\mathrm{Fe}-\mathrm{Al}$ analcime formation," Journal of Porous Materials, vol. 14, no. 4, pp. 443-448, 2007.
[32] M. Alkan, Ç. Hopa, Z. Yilmaz, and H. Güler, "The effect of alkali concentration and solid/liquid ratio on the hydrothermal synthesis of zeolite NaA from natural kaolinite," Microporous and Mesoporous Materials, vol. 86, no. 1-3, pp. 176-184, 2005.

[33] C. S. Cundy and P. A. Cox, "The hydrothermal synthesis of zeolites: precursors, intermediates and reaction mechanism," Microporous and Mesoporous Materials, vol. 82, no. 1-2, pp. 178, 2005.

[34] R. M. Barrer, "Ion-exchange and ion-sieve processes in crystalline zeolites," Journal of the Chemical Society, pp. 2342-2350, 1950.

[35] R. M. Barrer and L. Hinds, "Ion-exchange in crystals of analcite and leucite," Journal of the Chemical Society, pp. 1879-1888, 1953.

[36] W. D. Balgord and R. Roy, "Crystal chemical relationships in the analcite family I. Synthesis and cation exchange behavior," Advances in Chemistry, vol. 101, pp. 140-148, 1974.

[37] D. Taylor, "The sodalite group of minerals," Contributions to Mineralogy and Petrology, vol. 16, no. 2, pp. 172-188, 1967.

[38] H. Ghobarkar and O. Schäf, "Effect of temperature on hydrothermal synthesis of analcime and viséite," Materials Science and Engineering: B, vol. 60, no. 3, pp. 163-167, 1999.

[39] S. N. Azizi, A. A. Daghigh, and M. Abrishamkar, "Phase transformation of zeolite $\mathrm{P}$ to $\mathrm{Y}$ and analcime zeolites due to changing the time and temperature," Journal of Spectroscopy, vol. 2013, Article ID 428216, 5 pages, 2013.

[40] Y. Wang, X. Li, Z. Xue, L. Dai, S. Xie, and Q. Li, "Preparation of zeolite ANA crystal from zeolite Y by in situ solid phase Isostructure transformation," The Journal of Physical Chemistry B, vol. 114, no. 17, pp. 5747-5754, 2010.

[41] V. Y. Prokof'ev and N. E. Gordina, "Preparation of granulated LTA and SOD zeolites from mechanically activated mixtures of metakaolin and sodium hydroxide," Applied Clay Science, vol. 101, pp. 44-51, 2014.

[42] S. N. Azizi and S. Ehsani Tilami, "Framework-incorporated $\mathrm{Mn}$ and Co analcime zeolites: synthesis and characterization," Journal of Solid State Chemistry, vol. 198, pp. 138-142, 2013.

[43] R. M. Barrer, Hydrothermal Chemistry of Zeolites, Academic Press, London, UK, 1982.

[44] J. Bronić and B. Subotić, "Role of homogeneous nucleation in the formation of primary zeolite particles," Microporous Materials, vol. 4, no. 2-3, pp. 239-242, 1995.

[45] A. M. Cardoso, A. Paprocki, L. S. Ferret, C. M. N. Azevedo, and M. Pires, "Synthesis of zeolite Na-P1 under mild conditions using Brazilian coal fly ash and its application in wastewater treatment," Fuel, vol. 139, pp. 59-67, 2015.

[46] Y.-Y. Ge, Q. Tang, X.-M. Cui, Y. He, and J. Zhang, "Preparation of large-sized analcime single crystals using the GeopolymerGels-Conversion (GGC) method," Materials Letters, vol. 135, pp. 15-18, 2014. 

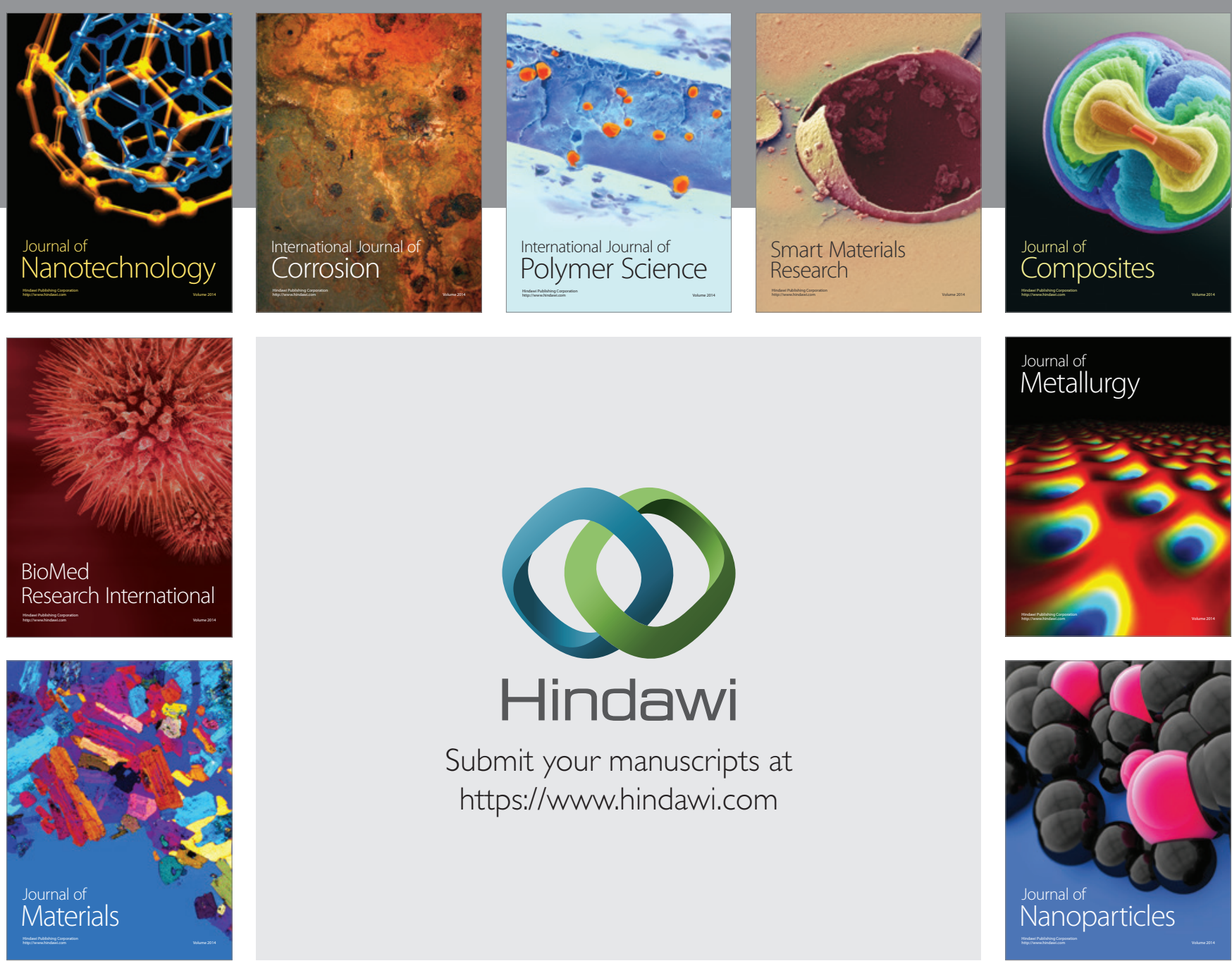

\section{Hindawi}

Submit your manuscripts at

https://www.hindawi.com

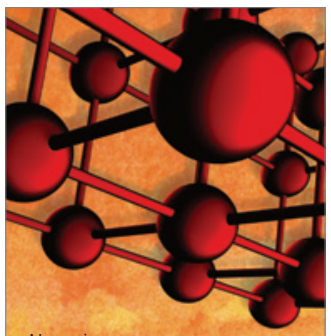

Materials Science and Engineering
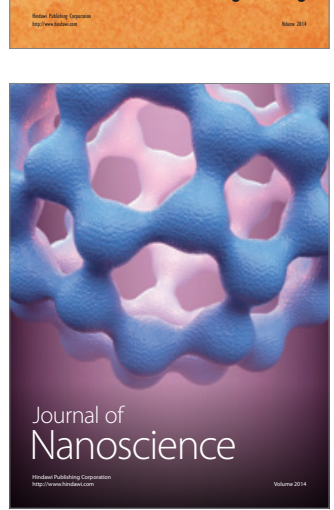
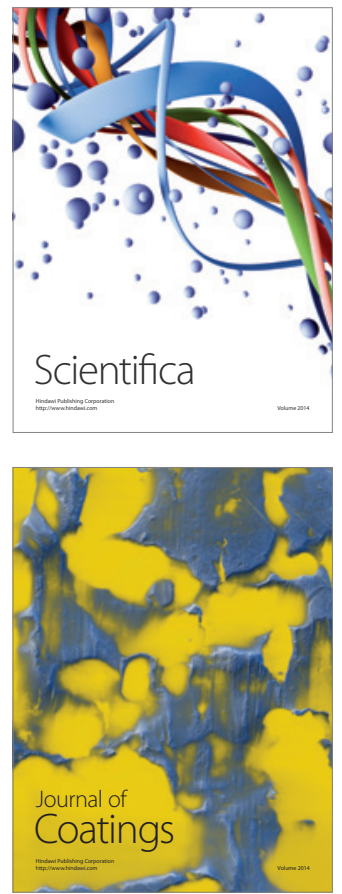
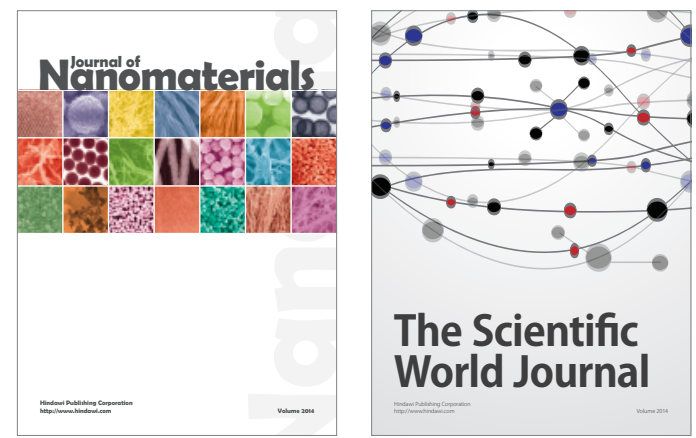

The Scientific World Journal
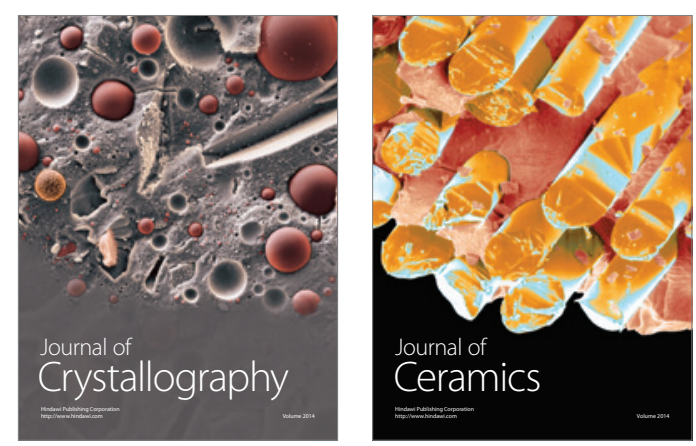
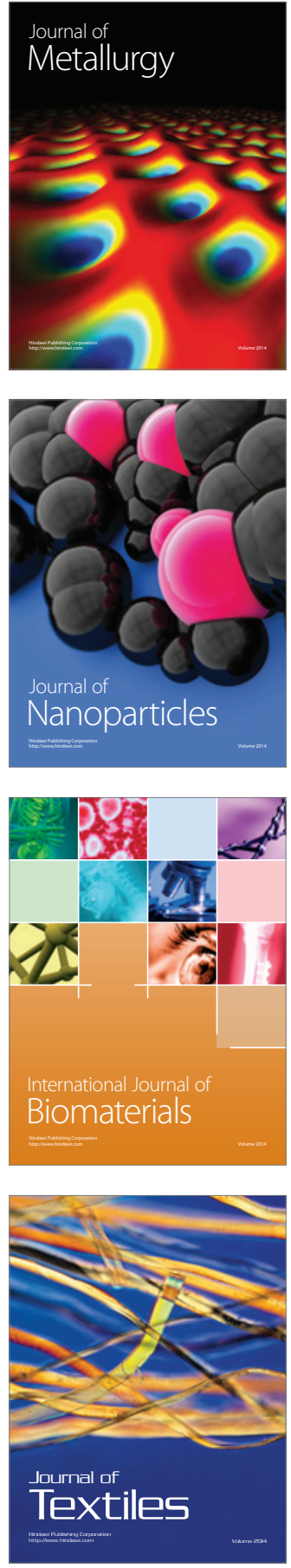